\title{
PSYCHOLOGICAL WELL-BEING OF EMPLOYEES IN JAVA, INDONESIA
}

\author{
Kiky Dwi Hapsari Saraswati ${ }^{1}$, Jeannyver Teja ${ }^{2}$ \\ ${ }^{1}$ Fakultas Psikologi, Universitas Tarumanagara Jakarta \\ Email:kikysaraswati@yahoo.com \\ ${ }^{2}$ Fakultas Psikologi, Universitas Tarumanagara Jakarta \\ jeannyfer.teja@gmail.com
}

\begin{abstract}
ABSTRAK
Performance is the main indicator for the company to measure productivity. Only productive employees will be retained by the company. Therefore, competition in the professional world forces employees to work hard. They often neglect their Psychological Well-Being (PWB), whereas PWB is proved to correlate with work performance and organization's effectiveness (Wright and Cropanzo in Robertson and Cooper, 2009). PWB is when a person shows that he is healthy, well, functions optimally and succeed despite life's existential challenges (Ryff and Keyes, 1995). Ryff (1995) mentioned several factors that affect PWB, including age, gender, and culture. This study aims to obtain an overview of PWB of employees working in Java, Indonesia. A quantitative approach is done by distributing the PWB Scale to 544 employees in six provinces. The result shows that the PWB is above average (mean= 3.49). According to gender, there is a significant difference between the $P W B$ of male and female employees ( $p<0.05)$. Also, employees who are in the range of 26-30 years old show better PWB $($ mean $=3.56)$ than older employees. We concluded that the PWB of employees in Java Island, Indonesia, is high. Male employees show better PWB than female (mean = 3.50). It indicates that male employees perceive that the opportunity to be more well-being are given more than female in their work place. Furthermore, PWB increases until when employees are 30 years and decreases as they grow older. It indicates that the younger ones perceive more opportunity to be wellbeing than older employees.
\end{abstract}

Keywords: Psychological Well-Being; Employees; Work; Java; Indonesia

\begin{abstract}
ABSTRAK
Kinerja adalah indikator utama bagi perusahaan untuk mengukur produktivitas. Hanya karyawan yang produktif yang akan dipertahankan oleh perusahaan. Maka, persaingan di dunia profesional memaksa karyawan untuk bekerja keras. Mereka sering mengabaikan Kesejahteraan Psikologi (PWB) mereka, meskipun PWB terbukti berkorelasi dengan kinerja kerja dan efektivitas organisasi (Wright dan Cropanzo dalam Robertson dan Cooper, 2009). PWB adalah ketika seseorang menunjukkan bahwa dia sehat, baik, berfungsi secara optimal dan berhasil meskipun ada tantangan existensial hidup (Ryff dan Keyes, 1995). Ryff (1995) menyebutkan beberapa faktor yang mempengaruhi PWB, termasuk usia, jenis kelamin, dan budaya. Penelitian ini bertujuan untuk memperoleh gambaran umum tentang PWB karyawan yang bekerja di Jawa, Indonesia. Pendekatan kuantitatif dilakukan dengan mendistribusikan Skala PWB kepada 544 karyawan di enam provinsi. Hasilnya menunjukkan bahwa PWB di atas rata-rata (rata-rata $=3,49)$. Menurut jenis kelamin, ada perbedaan yang signifikan antara PWB karyawan pria dan wanita $(p<0,05)$. Selain itu, karyawan yang berada dalam kisaran umur 26-30 tahun menunjukkan PWB yang lebih baik (rata-rata $=3,56)$ daripada karyawan yang lebih tua. Kami menyimpulkan bahwa PWB karyawan di Pulau Jawa, Indonesia, tinggi. Karyawan laki-laki menunjukkan PWB yang lebih baik daripada perempuan (rata-rata $=3,50)$. Ini menunjukkan bahwa karyawan laki-laki menganggap bahwa kesempatan untuk menjadi lebih sejahtera diberikan lebih banyak daripada perempuan di tempat kerja mereka. Selain itu, PWB meningkat hingga saat karyawan berusia 30 tahun dan menurun seiring bertambahnya usia. Ini menunjukkan bahwa karyawan yang lebih muda menganggap lebih banyak peluang untuk menjadi lebih sejahtera daripada karyawan yang lebih tua.
\end{abstract}

Kata kunci: Kesejahteraan Psikologis; Para karyawan; Kerja; Jawa; Indonesia 


\section{INTRODUCTION}

Indonesia has shown a promising growth in terms of economics and infrastructures in the last several years. Despite nationwide attempt, economic development still mostly concentrated at Java, as the most populated island. Therefore, Java has become the center of business where most of the economic activities take place.

Referring to Kuzgun (2003), job is a significant factor in conceptualizing identity of a person. Having an established occupation plays an important role for people to be self confident and respected in the society. People produce things as an output in their work, and show an effort to be happy by obtaining satisfaction through what they produce. Although the business recently has employed high technology, human being is still needed to run the systems. Consequently, the people have to improve their competence to keep up with technology advancement. Furthermore, they also have to work hard to stay competitive. Otherwise, they will be replaced by other people with better competence, or even machine. Competing costs many things like self-exploitation in the workplace. As the consequence of the competition, it is very common to find any kind of physical as well as psychological problems such as heart disease and stress. According to previous research results, the challenges in the work environment, characterized by higher competition, increased work targets, threats of job loss, organizational change, lack of time, lack of space, continuous technological development, and conflicting demands from management, have resulted a higher work stress (McHugh, 1997).

Feelings, thoughts, and behaviors occur at workplace can lead to the level of well-being. Many researches found that well-being contributes a significant impact towards work performance. People who show higher Psychological Well-Being (PWB) most likely show greater flexibility and originality, respond better on unfavorable feedback, give more positive judgments about others, show higher levels of engagement, are more productive, are likely to live longer, be sick less often, and have happier work and family life (Lyubomirsky, King, and Diener, 2005).

PWB can be defined in many ways. Deci and Ryan (2008) stated that PWB is usually conceptualized as some combination of positive affect such as happiness (the hedonic perspective) and functioning with optimal effectiveness in individual and social life (the eudaimonic perspective). In other words, Huppert (2009) summarized it as lives going well and a combination of feeling good and functioning effectively. Furthermore, Winefield, Gill, Taylor, and Pilkington (2012) described that people with high PWB report that they feel happy, capable, well-supported, satisfied with life, and so on. On the other hand, PWB is also discussed in terms of health-related quality of life such as anxiety, depression, self-control, general health, and vitality (Hallberg, Hallberg \& Kramer, 2008).

In this research, we are focusing the discussion only in terms of the happiness of individuals within the framework of several variables. McGregor and Little (1998) expressed well-being as related to evaluating the meaning of life and purposes in life. Ryan and Deci (2001) explained well-being with psychological needs. According to them, basic psychological needs are 
autonomy, competence, and established relationships. Well-being is when these needs are fulfilled. The concept of PWB was defined as striving for challenge, making efforts, personal development and growth by Waterman (1993).

Ryff (1989) defined PWB as achieving a state of balance affected by both challenging and rewarding life events. Moreover, well-being should be explained through an integrative understanding benefiting from life development, mental health and clinical viewpoint. Being different from happiness, well-being has been discussed as individuals' effort to realize their own real potential. Ryff (1995) stated that happiness was not the key message, and happiness could be as result of a good life. A good life or PWB includes positive relationships with others, environmental mastery, autonomy, purpose in life, personal growth, and self-acceptance. Taken together, these six dimensions encompass a breadth of wellness that includes positive evaluations of one's self and life, a sense of continued personal growth and development, the belief that life is purposeful and meaningful, having good relationships with others, the capacity to manage one's life and the surrounding effectively, and a sense of self-determination. When the concept of PWB is applied in the occupational life, it can be defined as individuals' building positive relationships with people, occupational acceptance, personal development, fulfilling life and occupational needs, and willing to personally develop themselves.

PWB is influenced by many factors such as age, employment, marital status, personality and negative life events (Skomorovsky \& Sudom, 2011). PWB is affected by inner processes such as personality, temperament, etc., and can also be affected by occupational factors such as occupation, work environment, and job satisfaction. The job itself may affect both job satisfaction and PWB. An occupational life in coherence with interests, abilities and values can positively affect the level of job satisfaction, and this positively reflects on PWB. Employees with positive attitude towards the job are happier and more satisfied with themselves. On the other hand, employees with negative attitudes towards their job may experience several emotional, mental and physical problems (Maslach \& Leiter, 1997). In other words, work as a big part of life can be assessed as one of the fundamental factors of PWB.

Research has suggested that there is a correlation between PWB and multiple dimensions of a person's life, including marital satisfaction, general health, and work-life balance. Prior research suggests that there are significant gender differences as it relates to PWB. Dimenas, Carlsson, Glise, Israelsson, \& Wiklund (1996) found that in general population Swedish men tend to have a higher level of PWB than women. Another research concluded that there are not only gender differences as it relates to PWB, but that the workplace setting may also play a significant role.

Karunanidhi and Chitra (2013) tried to reveal factors affecting PWB of policewomen. They found that occupational stress, work-life balance, job attitude, and personality contributed to PWB. Another research found that types of work also contribute to Psychlogical Well-Being. Focusing on types of work, female teachers were found to have higher well-being compared to women working in banks, who in turn, had higher well-being than women working in industry (Srimathi and Kiran Kumar, 2010). 
Studies have found that PWB has a positive influence both on people's health and attitudes. For example, individuals with higher well-being are found to be more productive and having better mental and physical health compared to those with lower well-being (Ryff \& Singer, 2002). Moreover, in workplace setting, PWB also significantly correlates with work performance (Cropanzano and Wright, 1999). Another research conducted by Harter, Schmidt and Keyes (2003) concluded that well-being correlated with business unit performance, such as sickness, absence, customer satisfaction, productivity, employee turnover, etc. Lyubomirsky et al. (2005) also found that people with higher PWB most likely show higher flexibility and originality, respond better towards unfavorable feedback, give more positive judgments about others, show higher levels of engagement, are more productive, are likely to live longer, be sick less often, and have a happier work and family life.

Employees with higher well-being show more positive attitudes and respond better to various situations in life compared to those lower on well-being (Ryff \& Keyes, 1995). In contrast, people with lower levels of well-being are more likely to see neutral or ambiguous events as threatening (Seidlitz, Wyer \& Diener, 1997) which is likely to cause problems in an organizational setting where changes happen. Further evidence shows that negative feedback is seen as more hurtful by people with lower PWB and positive feedback produces fewer benefits for them. Considering the importance of well-being, this research aims to describe PWB of employees in Java, Indonesia. This finding will be an important input for companies to develop programs to increase the well-being of their employees. In return, companies may expect increased employee's productivity as well as the increased company's performance.

\section{METHODS}

A total of 544 participants took part in this study. The participants were randomly recruited via various institutions, both profit and non profit, from six provinces in Java Island, Indonesia. The data showed that most of the participants were male (355 persons or 65,26\%), while female participants were 189 persons $(34,74 \%)$. The ages of the participants ranged from 18 to 55 years old. The age data was classified into 5 groups. Participants below 25 years old were accounted for 148 participants $(27,20 \%), 26-30$ years old were accounted for 120 participants $(22,06 \%)$, 31-35 years old were accounted for 54 participants (9,93\%), 36-40 years old were accounted for 66 participants $(12,13 \%)$, whereas those with ages more than 40 years old were accounted for 156 participants $(28,68 \%)$.

This study is a quantitative research. To analyse the data, descriptive analysis was used to investigate the description of PWB of employees in Java Island, Indonesia. Data was collected by distributing 15-item Psychological Well-Being Scale (Cronbach's Alpha = 0,706) to participants. This scale was developed based on Ryff's concept of PWB, which consisted of six dimensions of PWB: Self-Acceptance (e.g., "When I look at the story of my life, I am pleased with how things have turned out"), Personal Growth (e.g., "For me, life has been a continuous process of learning, changing, and growth"), Purpose in Life (e.g., "Some people wander aimlessly through life, but I am not one of them"), Positive Relations With Others (e.g., "People would describe me as a giving person, willing to share my time with others"), Environmental 
Mastery (e.g., In general, I feel I am in charge of the situation in which I live"), Autonomy (e.g., "My decisions are not usually influenced by what everyone else is doing").

\section{RESULT AND DISCUSSION}

The PWB description is presented in Table 1. In general, employees in Java Island show high PWB. The mean of all dimensions is 3,49 , which is higher than the empiric mean. When we look deeper, each dimension also showed high score. The highest is Personal Growth, while the lowest is Autonomy.

Table 1. Mean per Dimension

\begin{tabular}{lcccccc}
\hline & PWB_A & PWB_EM & PWB_PG & PWB_PR & PWB_PL & PWB_SA \\
\hline Mean & 3.2420 & 3.7855 & 3.8070 & 3.3211 & 3.6176 & 3.2678 \\
\hline
\end{tabular}

In terms of sex, male employees show higher PWB (mean $=3.505)$ than female $($ mean $=3.489)$. Also, there is a significant difference between male and female respondents. The result is as shown below in Table 2 .

Table 2. Difference per Sex

Mann-Whitney U

Wilcoxon W

$\mathrm{Z}$

Asymp. Sig. (2-tailed)
MEAN_PWB_TOT

28937.000

46892.000

$-2.548$

.011

Difference in PWB dimensions shown in Table 3. It is clear that significant difference in terms of sex are in 5 of 6 dimensions (Autonomy, Environmental Mastery, Personal Growth, Purpose in Life, and Self-Acceptance). There is no significant difference in Positive Relation dimension.

Table 3. Difference per Dimension (Sex)

\begin{tabular}{ccccccc}
\hline & MEAN & MEAN & MEAN & MEAN & MEAN & MEAN \\
& PWB_A & PWB_EM & PWB_PG & PWB_PR & PWB_PL & PWB_SA \\
\hline Mann-Whitney U & 29016.00 & 29739.00 & 29846.00 & 30422.00 & 29899.00 & 28080.50 \\
Wilcoxon W & 46971.00 & 47694.00 & 47801.00 & 48377.00 & 92380.00 & 46035.50 \\
Z & -2.529 & -2.130 & -2.103 & -1.721 & -2.016 & -3.075 \\
Asymp. Sig. (2- & .011 & .033 & .035 & .085 & .044 & .002 \\
\hline
\end{tabular}


tailed)

In terms of age, the highest PWB is shown in the range of 26-30 years old (mean = 3.556). Significant difference is also shown in terms of age. Here is the result of the data analyze.

Table 4. Difference per Age

\begin{tabular}{lc}
\hline & MEAN_PWB_TOT \\
\hline Chi-Square & 24.467 \\
Df & 4 \\
Asymp. Sig. & .000 \\
\hline
\end{tabular}

In detail, when we take a look at the dimensions, there is a significant difference in all dimensions, except Purpose in Life. The result is shown below.

Table 5. Difference per Dimension (Age)

\begin{tabular}{lcccccc}
\hline & MEAN & MEAN & MEAN & MEAN & MEAN & MEAN \\
& PWB_A & PWB_EM & PWB_PG & PWB_PR & PWB_PL & PWB_SA \\
\hline Chi-Square & 27.867 & 14.587 & 11.657 & 9.986 & 8.070 & 15.291 \\
Df & 4 & 4 & 4 & 4 & 4 & 4 \\
Asymp. Sig. & .000 & .006 & .020 & .041 & .089 & .004 \\
\hline
\end{tabular}

\section{Discussion}

As described in the results above, the PWB of employees in Java is categorized above the average. It means that they are capable to accept themselves the way they are, have established quality ties to others, a sense of autonomy in thought and action, the ability to manage complex environments to suit personal needs and values, the pursuit of meaningful goals and a sense of purpose in life, as well as continued growth and development as a person. When we look deeper, the highest average is Personal Growth. According to Ryff (1995), this finding indicates that the employees have a feeling of continued development, see themselves as growing and expanding are open to new experiences, have sense of realizing their potential, see improvement in themselves and behavior over time, are changing in ways that reflect more self-knowledge and effectiveness.

The result also shows that there is a significant difference of PWB between male and female employees. In this research, it is found that male employees reported higher PWB than female employees. Although it is a bit different from what Ryff (1995) concluded in her previous research that women of all ages consistently rate themselves higher on Positive Relations with others than do men, and that women tend to score higher than men on Personal Growth, this result supports what Dimenas et al (1996) found, that in the general population Swedish men 
tend to have a higher level of PWB than women. Prior researches conducted in other countries also showed the same results. In Taiwan, it was discovered a gender difference while examining conjugal congruence on role experiences and subjective well-being. The same case was also found in a mental health study in Canadian population. This finding also indicates that there's still an unequal opportunity to nurture PWB in the society. Basically, all people have the same right to optimize their potential, so that they are able to cope and function better in their environment. In other words, people should be given the same opportunity to promote their optimal PWB.

Further analysis finds gender differences in 5 of 6 dimensions of PWB. The 5 dimensions are Autonomy, Environmental Mastery, Personal Growth, Purpose in Life, and Self Acceptance. Employees have a different perspective about the evaluation of themselves and their past lives, the capacity to effectively manage their lives and the surrounding world; a sense of selfdetermination and the ability to resist social pressures to think and act in certain ways, the sense of continued growth and development as a person as well as openness to new experiences; and the belief that their lives are purposeful and meaningful and that they have something to live for. This finding is quite different compared to what Ryff (1995) found. In other researches she had conducted, it was found that there are no significant differences in Autonomy, Environmental Mastery, Purpose in Life, and Self-Acceptance.

On the other hand, there is no significant gender difference found in Positive Relation. It may be interpreted that both male and female employees feel that they have warm, satisfying, trusting relationships with others. They also are concerned about the welfare of others, capable of strong empathy, affection, and intimacy, and understand the give and take of human relationships. This finding does not support what Ryff (1995) found in other researches that women of all ages consistently rate themselves higher on Positive Relation with others than do men.

According to the research result, employees who are younger than 30 years old show the highest level of PWB. It declines as they grow older. This finding also support what Ryff wrote. Ryff (2014) reported that younger and middle-aged adults saw themselves as improving over time, whereas older adults anticipated decline in their well-being in the years ahead. Significant difference is also shown in terms of age. In detail, it is shown in all dimensions, except Purpose in Life. It can be interpreted that at certain ages, employees place more value on some dimensions and less value on others. This is also explained by Ryff (1995) when she filed some conclusions of her researches. According to Ryff's conclusion, older people place less value on some dimensions, such as Personal Growth and Purpose in Life. In the contrary, they place more value on Environmental Mastery and Autonomy. A bit different from Ryff's conclusion, this research found out that there is no significant difference in Purpose in Life. We can also say that employees of all ages have the same belief that they have a purposeful and meaningful life and they have something to live for. 


\section{CONCLUSION}

Well-being is often considered to be a luxury for developing countries. Employees struggle to stay employed in the middle of the fast technology development and industrial modernism. Therefore, they sometimes neglect how to nurture their well-being, and focus their attention in the workplace instead. Referring to the research result, we concluded that Indonesian employees who work in various business show a quite good PWB. And it's quite surprising that male employees reported a higher well-being than female employees. It indicates that, based on gender, the opportunity to have a happy life is still unequal. Another conclusion that we obtained from the study is that well-being increases until the age of 30 years old. As they grow older they tend to perceive that life is not functioning as they expect. This finding can be a beneficial input for Indonesian government to launch related programs to increase the equal opportunity for all genders of all ages to promote well-being. Also, it is very recommended for the government to pay more attention to create a psychological healthier workplace condition.

To have a broader description of PWB among employees in Indonesia, we suggest to put more information in future researches, such as tenure, positions, and areas of business. This information is closely related to employees for it is believed that well-being in the workplace depends on working and organizational environment within employees do their routine work.

\section{Acknowledgement}

We thanked Direktorat Penelitian dan Pengabdian Masyarakat Universitas Tarumanagara for funding this research.

\section{REFERENCES}

Cropanzano, R., \& Wright, T. A. (1999). A 5-year study of change in the relationship between well-being and job performance. Consulting Psychology Journal, 51(4), 252-265.

Deci, E. L., \& Ryan, R. M. (2008). Facilitating optimal motivation and psychological well-being across life's domains. Canadian Psychology, 49(1), 14-23.

Hallberg, L. R., Hallberg, U., \& Kramer, S. E. (2008). Self-reported hearing difficulties, communication strategies and psychological general well-being (quality of life) in patients with acquired hearing impairment. Disability and Rehabilitation, 30(3), 203-212.

Harter, J. K., Schmidt, F. L., \& Keyes, C. L. M. (2003). Well-being in the workplace and its relationship to business outcomes: A review of the Gallup studies. In C. L. M. Keyes \& J. Haidt (Eds.), Flourishing: Positive psychology and the life well-lived (pp. 205224). Washington, DC: American Psychological Association.

Huppert, F. (2009). Psychological well-being: Evidence regarding its causes and consequences. Applied Psychology: Health and Wellbeing, 1(2), 137-164. 
Karunanidhi, S., \& Chithra, T. (2013). Influence of select psychosocial factors on the psychological well-being of policewomen. International Research Journal of Social Science, 2(8), 5-14.

Kuzgun, Y. (2003) Introduction to professional guidance and counselling. Ankara: Nobel.

Lawson, K. J., Noblet, A. N., \& Rodwell, J. J. (2009). Promoting employee wellbeing: The relevance of work characteristics and organizational justice. Health Promotion International, 24(3), 223-233.

Lyubomorsky, S., King, J., \& Diener, E. (2005). The benefits of frequent positive affect: Does happiness lead to success? Psychological Bulletin, 131(6), 803-855.

Maslach, C., \& Leiter, M. P. (1997). The truth about burnout. New York, NY: Jossey-Bass.

McGregor, I., \& Little, B. R. (1998). Personal projects, happiness, and meaning: On doing well and being yourself. Journal of Personality \& Social Psychology, 74(2), 494-512.

McHugh, M. (1997). The stress factor: Another item for the change management agenda? Journal of Organizational Change Management, 10(4), 345-362.

Robertson, I., \& Cooper, C. (2009). Full engagement: The integration of employee engagement and psychological well-being. Leadership and Organizational Development Journal, 31(4), 324- 336.

Ryan, R. M., \& Deci, E. L. (2001). To be happy or to be self-fulfilled: A review of research on hedonic and eudaimonic well-being. In S. Fiske (Ed.), Annual review of psychology (pp. 141-166). Palo Alto, CA: Annual Reviews/ Inc.

Ryff, C. D. (1989). Happiness is everything, or is it? Explorations on the meaning of psychological well-being. Journal of Personality and Social Psychology, 57(6), 10691081.

Ryff, C. D. (1995). Psychological well-being in adult life. Current Directions in Psychological Science, 4(4), 99-104.

Ryff, C. D. (2014). Psychological well-being revisited: Advances in science and practice. Psychother Psychosom, 83(1), 10-28.

Ryff, C. D., \& Keyes, C. (1995). The structure of psychological well-being revisited. Journal of Personality and Social Psychology, 69(4), 719-727.

Ryff, C. D., \& Singer, B. (2002). From social structure to biology: Integrative science in pursuit of human health and well-being. In C. R. Snyder \& S. J. Lopez (Eds.), Handbook of positive psychology (pp. 541-554). New York, NY: Oxford University.

Seidlitz, L., Wyer, R. S., \& Diener, E. (1997). Cognitive correlates of subjective well-being: The processing of balanced life events by happy and unhappy persons. Journal of Research in Personality, 31, 240-256.

Skomorovsky, A., \& Sudom, K. A. (2011). Role of hardiness in the psychological well-being of Canadian Forces officer candidates. Military Medicine, 176(1), 7-12. 
Srimathi, N. L, \& Kiran Kumar, S. K. (2010). Psychological well-being of employed women across different organisations. Journal of the Indian Academy of Applied Psychology, 36(1), 89-95.

Waterman, A. S. (1993). Two conceptions of happiness: Contrasts of personal expressiveness (eudaimonia) and hedonic enjoyment. Journal of Personality and Social Psychology, 64(4), 678-691.

Winefield, H. R., Gill, T. K., Taylor, A. W., \& Pilkington, A. R. (2012). Psychological wellbeing and psychological distress: Is it necessary to measure both? Psychology of WellBeing: Theory, Research and Practice, 2(3), 1-14. 